Kafkas Üniversitesi Sosyal Bilimler Enstitüsü Dergisi

Kafkas University Journal of the Institute of Social Sciences

Sonbahar Autumn 2021, Sayı Number 28, 405-414

DOI:10.9775/kausbed.2021.022

Gönderim Tarihi: 21.09.2021

Kabul Tarihi: 06.12.2021

THE FLIES: A STORY OF TRANSFORMATION FROM BAD FAITH INTO CONSCIOUSNESS

\title{
Sinekler: Kendini Aldatmadan Bilince Giden Bir Dönüşüm Hikayesi
}

Sevcan IŞIK

Assistant Proffesor, İnonu Univrsity,

Western Languages and Literatures Department, sevcanakcag@hotmail.com,

ORCID ID: 0000-0002-4696-330X

Çalışmanın Türü: Araştırma

$\ddot{O} z$

Bu çalışmanın amacı Sinekler adlı oyunu Sratre'ın varoluşçuluk felsefesinde kullandiğ kendini aldatma ve bilinç kavramları ışı̆̆ında incelemektir. Sartre'a göre insanlar özgür varliklardır ve bu yüzden eylemlerinin sorumluluklarını almak zorundadırlar. Oyunda, oyunun başkarakteri Orestes babası Agamemnon'un intikamını almak için Argos şehrine gelir. Zeus onun şehri sonsuza kadar terk etmesini ister fakat Orestes başka bir yolu da seçebileceğini fark eder. Bu farkındalık çok önemlidir çünkü Orestes eylemlerinin sonuçları için ne bir tanrıy ne de başka diş kaynaklı faktörleri sorumlu tutamaz. Ancak ne yapacağını seçme konusunda özgür olduğunu fark ettikten sonra oyun Orestes' 'in kendisini bulma yolculuğuna dönüşür. Böylece bu yolculuğun sonunda Orestes açısından bakıldığında kendini aldatmadan bilinçliliğe dair bir dönüşüm söz konusudur.

Anahtar Kelimeler: Sartre, Orestes, Sinekler, kendini aldatma ve bilinç

Abstract

This study aims to analyze the play called the Flies by analyzing the protagonist of the play, Orestes, in the light of Sartre's existentialist terms bad faith and consciousness. In the play, the protagonist Orestes arrives the city of Argos to avenge the death of his father Agamemnon. Zeus wants him to leave the city for good; nonetheless, Orestes realizes that he can choose another way. This recognition is very important in that he cannot blame God or other external factors for the consequences of his action. However, after realizing that he is free to choose, the play becomes a quest for self for Orestes. At the end of the quest, there is a transformation from bad faith to consciousness for Orestes.

Keywords: Sartre, Orestes, the Flies, bad faith, and consciousness.

Following the great atrocities caused by the two world wars, people began to feel alienated and disappointed, which was resulted in the loss of faith in religion and in social institutions. Interestingly enough, existentialist movement became popular in post-war period since man was seen as an individual who was totally responsible with their actions in this movement. Being an influential figure in this movement, French philosopher Jean Paul Sartre also emphasized the importance of freedom to choose one's own life. Sartre claims "existence precedes essence" (Sartre, 1947: 28). Therefore, he explains that self is not a fixed entity but it is in flux. This idea necessitates that there is not a universal human nature and individuals should create their 
identities and their lives' meanings. An individual is responsible for who he is now and who will be in the future. The individual will achieve this through making choices with his freedom and responsibility. Sartre rejects the idea of God, thus, he gets rid of the excuses. People do not take the responsibilities of their actions either by accepting a universal nature of man or by believing in God. He states: "Man is not only that which he conceives himself to be, but that which he wills himself to be, and since he conceives of himself only after lie exists, just as he wills himself to be after being thrown into existence, man is nothing other than what he makes of himself. This is the first principle of existentialism" (Sartre, 1947: 28).

Sartre also explains that things exist either as being in itself or as being for itself. Sartre states that "being is what it is" (Sartre, 1992: 29). Being in itself means that things exist without consciousness in the world and they cannot realize themselves. As for, being for itself, "(B)eing is what it is not, and is not what it is". To say that "being-for-itself is not equal to itself' means that consciousness does not have a fixed nature (Sartre, 1992: 113). It refers to consciousness and free will. Consciousness and free will are very important terms for Sartre as he believes that there is not an outside force on individuals' wills. Therefore, Sartre wants the individuals to be true themselves by taking the responsibilities of their actions instead of making external forces responsible for their actions. Otherwise, the individuals perform bad faith and become inauthentic.

According to Sartre, an individual is free to act in a certain way as a result of his being free to choose he/she cannot excuse for his/her bad decisions. Sartre defines this reaction as bad faith (Sartre, 1947: 47). He considers bad faith as a sort of lie because individuals blame external forces for their actions instead of accepting that they are free. He also explains: "If we define man's situation as one of free choice, in which he has no recourse to excuses or outside aid, then any man who takes refuge behind his passions, any man who fabricates some deterministic theory, is operating in bad faith" (Sartre, 1947: 47). Sartre does not approve those who try to evade from their responsibilities by blaming the external factors although they have freedom to choose. This is bad faith.

Sartre is highly influenced by German philosopher Martin Heidegger who defines freedom "as a possibility of good and evil" (Heidegger, 1985: 97). There may be coercive reasons but human beings, by means of 'freedom' and 'will', are the ultimate authority to choose something. Inasmuch as 'choice' is included, one should mention 'will' or 'free will'. Free will is defined as "the power of agents to be the ultimate creators (or 
originators) and sustainers of their own ends and purposes" (Kane, 2000: 315). As seen, it is not easy to make a strict line between freedom and free will since free will necessitates freedom and freedom is a prerequisite of free will. However, the nuance can be indicated as "to act freely is to be unhindered in the pursuit of your purposes; to will freely is to be the ultimate source or creator of your own purposes" (Kane, 2000: 315). In short, if there is not any obstacle for one to fulfil an action $\mathrm{s} / \mathrm{he}$ is free, then. 'Will', on the other hand, is the choice one intends to do something with full responsibility and intentionally only when $\mathrm{s} / \mathrm{he}$ is free. Once having decided for an action there will be no room for remorse or repentance because remorse makes the action invalid (Williams, 2008: 380).

Moreover, Sartre describes freedom as a curse rather than a choice. A dialogue between Sartre and one of his students summarizes succinctly this situation. When one of Sartre's students ask him whether he should go to army where he will fulfil his duty and be named as a patriot; however, his mother is dependent on him and she will die if he enrols. Upon this, Sartre replies him "you are the free creator of what you are going to be, a true son and a betrayer, or a murderer of your mother and a patriot" (Amstutz, 1961: 257). This shows the fact that an individual creates himself with consciousness and free will. Thus, the individuals do not have unchanged or substantial natures. Similarly, Orestes affirms "human life begins on the far side of despair" (Sartre, 1989: 66) as he becomes an outcast in the society. Even if he wants to remorse he cannot because of the fact that he knows he is free and describes himself by saying "I was like a man who's lost his shadow. And there was nothing left in heaven, no right or wrong, nor anyone to give me orders" (Sartre, 1989: 65).

As for the play, Agamemnon, the king of Argos, is narrated as a good king loved by his subjects. One day, he abolishes the public execution which is not welcomed by the public of Argos who love watching violent deaths as an entertainment. This is why, they do not warn the king against the plotting of his wife Clytemnestra and her lover Aigetheus. Zeus, in the guise of an old man in the play, comments "there's evil brewing. But they kept silence" (Sartre, 1989: 28-9). Thus, Zeus punishes them because they could have prevented the crime by warning the king beforehand although they were free to do it. By keeping silent themselves, they choose to act in a particular way. As a result, they have to take on the responsibility of this choice. In this sense, Raymond Critch (2013) asserts "while all creatures are condemned to action, only those with self-consciousness are condemned to choice" (278). Critch uses the word 'condemned' because there is no escape from choice. 
Similarly, Ronald E. Santoni (2008) declares "the freedom of choosing but not the freedom of not choosing. Not to choose is, in fact, to choose not to choose" (789).

For instance, the children ask for forgiveness from the dead in the play:

Please forgive us. We didn't want to be born, we're ashamed of growing up. What wrong can we have done you? It's not our fault if we're alive. And only just alive; see how small we are, how pale and puny. We never laugh or sing, we glide about like ghosts. And we're so frightened of you, so terribly afraid. Have mercy on us. The men forgive us for living while you are dead. (Sartre, 1989: 44)

While the children are pledging for forgiveness they ask that what wrong they can have done to the dead. In addition, they state that being alive is not their fault. These two statements are important in that they reveal that people cannot be responsible for the actions they have not performed freely. Otherwise, 'will' and 'freedom' will be meaningless and all the actions of people will be beyond 'good' and 'evil'. Through this quotation, Sartre ridicules the original sin doctrine because he gives priority 'freedom' and 'responsibility' above everything else. In addition to the public, Aegistheus also feels fearful and Clytemnestra reveals "the dead are underground and will not trouble us for many a long day. Have you forgotten it was you yourself who invented that fable to impress your people?" (Sartre, 1989: 53). As it is seen, Aegistheus makes up a story about the dead in order to scare his public and people believe this story. Although they are free to choose to do anything they act according to the wishes of their king. They cannot find their true selves by acting in this way. After this so-called story, people repent from their evil deeds by wishing forgiveness from dead people. Thus, public remorse for what they have done to their former king until Orestes comes into the city. In addition, Aegistheus's making up a story about the dead may be taken as a criticism against religion and other social institutions. Sartre may mean that all stories or ideas are made up by people for various reasons, which makes them subject to question. Thus, individuals should their own meaning in life by making choices.

When Orestes comes into the city of Argos he does not feel that he belongs to the city by confessing to his tutor "these folk are no concern of mine. I have not seen one of their children come into the world, nor been present at their daughters' weddings; I don't share their remorse, I don't even 
know a single one of them by name" (Sartre, 1989: 49). He feels distressed because he does not have an identity or self in Sartre's word as he feels displaced. He further mentions "I want to be a man who belongs to some place, a man among comrades" (Sartre, 1989: 49). Thus, he exists ontologically but looks for a self. In this context, Timothy J. Williams mentions Sartre's philosophy with "Sartre's three words 'existence precedes essence'; thereby, people refuse all a priori definitions of a human being". (376). Another interesting point is that nobody can help him in this situation. He should create his own meaning about his existence and about life. Before coming to Argos, he feels that he belongs to Argos. However, he does not share a least common ground with the public of it. Once having witnessed this, he does not dare to claim the kingdom of Argos.

On the other hand, his sister Electra provokes him to take revenge both for their father and for herself since she is forced to work like a slave in the palace. In spite of the fact that he has thought deeply about what to do he cannot have a definite decision and visits temple of Zeus to ask for a sign showing him what to do. He remarks:

Ah, if only I knew which path to take! O Zeus, our Lord and King of Heaven, not often have I called on you for help, and you have shown me little favor; yet this you know: that I have always tried to act aright. But now I am weary and my mind is dark; I can no longer distinguish right from wrong. I need a guide to point my way... Make plain your will by some sign; for no longer can I see my path. (Sartre, 1989: 50-1)

Because he does not have his self he does not know how to act. In response to his wish for a sign, being delighted from the situation, Zeus immediately gives a lighting that means to leave the city for good. Orestes gets the sign but instead of accepting it he, surprisingly, utters that "there is another way" (Sartre, 1989: 50). This is the turning point which makes him realize his freedom. Thus, the lightening Zeus sends to Orestes is both literally and metaphorically enlightening for Orestes. At the time of decision Orestes becomes aware of his being free, as it is claimed "I am never free except in situation" (Santoni, 2008: 789). In a similar vein, people act when the causes enter just like water acts as soon as it is put into a certain repository (Ken and Janaway, 2006: 341). In other words, because Orestes can choose a different way instead of accepting the signal sent by Zeus he realizes that he is free to act in a certain way instead of other way. After this milestone moment, he refuses to accept any established values declaring "I'll take no one's orders, neither man's nor god's" (Sartre, 1989: 51). As mentioned 
before, Sartre proposes human beings are being for itself creatures (Jones, 1980: 234). That's to say, they have conscious and, accordingly, do not have predetermined, unchanged natures. In contrast, they find a self and engage with it without giving any credit for established values. Human consciousness causes the world to be as it is, and so it is entirely responsible for the world (Jones, 1980: 235). They do it with their freedom of choice. For example, Orestes could have accepted the sign and left the city but he chose to do the opposite. And as a price for freedom, he will shoulder all the responsibility of his action no matter what the outcome is

After witnessing that Orestes is aware of his freedom Zeus warns Aegistheus to be careful against Orestes. Instead of feeling grateful for this information, Aegistheus feels resentful and reacts to Zeus asking "if today you hinder the crime Orestes has in mind, why did you permit mine of fifteen years ago?" (Sartre, 1989: 55). Thereupon, Zeus responds with a long speech, which makes Aegistheus more resentful:

All crimes do not displease me equally. And now, Aegistheus, I shall speak to you frankly, as one king to another. The first crime was mine: I committed it when I made man mortal. Once I had done that, what was left for you, poor human murderers, to do? To kill your victims? But they already had the seed of death in them; all you could do was to hasten its fruition by a year or two. Do you know what would have befallen Agamemnon if you had not killed him? Three months later he'd have died of apoplexy in a pretty slave-girl's arms. But your crime served my ends. (Sartre, 1989: 55)

Zeus is portrayed as a cruel god and indifferent to the needs of his people. Aigetheus blames Zeus for his murder of Agamemnon. This is a common habit among people who are ready to blame God or other people for their actions. However, this means the denial of freedom of people and a sort of lie to themselves. Acting in this way, people perform bad faith. Sartre refuses God and other external factors as responsible agents of individuals' actions. That is why, Sartre and many postwar existentialist thinkers are atheists. They put the individuals at the center of the universe and individuals decide who they are. As another example, after Zeus is persuaded that Orestes never retreats, Zeus concedes "well, Orestes, all this was foreknown. In the fullness of time a man was to come, to announce my decline. And you're that man, it seems. But seeing you yesterday-you with your girlish face-who'd have believed it?" (Sartre, 1989: 66). Seeing that Zeus foreknows the future but cannot prevent it proves the freedom of 
people once more. This also shows that there is no power over man's will. Once an individual decides to act nothing can stop him/her except for his/her own will. Thus, Orestes does not do what he is predetermined to do and acts freely.

Having learnt that Orestes is aware of his freedom, Aegistheus gives up arguing with Zeus about past and discloses "then, to lay hands on him, to put him in irons, is not enough. A free man in a city acts like a plague-spot... He will infect my whole kingdom and bring my work to nothing" (Sartre, 1989: 57). His fear will be more understandable when his obsession with the order in the society is recognized. A free man is seen dangerous by dictators like Aegistheus because he cannot be forced to act in a certain way since he feels that that he is responsible only for his actions. Besides, he evaluates his actions as good or evil only according to his value system not according to an established one. Thus, he denies any kind of authority over his will.

Thus, Aegistheus wonders why Zeus does not kill Orestes with a thunder, which is not a hard task for Zeus. However, Zeus's response is striking. He confides "once freedom lights its beacon in a man's heart, the gods are powerless against him. It's a matter between man and man, and it is for other men, and for them only, to leave him go his gait, or to throttle him" (Sartre, 1989: 62). Zeus as a god is portrayed as if he was only capable of creating human beings. He does not have any power on them. So, Sartre, in a sense, denies the existence of god by reducing God as powerless against man's freedom of choice to act. For instance, feeling weak against Orestes Zeus offers him forgiveness on condition that he accepts to feel remorse. Notwithstanding, he refuses the offer by telling "remorse? Why should I feel remorse? I am only doing what is right" (Sartre, 1989: 62). Then, he adds "I am no criminal, and you have no power to make me atone for an act I don't regard as a crime" (Sartre, 1989: 62). Orestes finds his essence and lives according to it without accepting god or any established values. In Sartre's terms, Orestes lives authentically. Because he is the subject of his life and has ultimate responsibility for it he gives the values to the things that do not have inherent meaning in them.

Upon that, Zeus opposes harshly claiming "what is right is the will of God...I made the world according to my will, and I am Goodness. But you, Orestes, you have done evil, the very rocks and stones cry out against you" (Sartre, 1989: 65). The discourse of Zeus is very oppressive claiming himself as the authority, and, naturally, as the representative of goodness. None the less, Orestes does not retreat, conversely, he fights for his new discovered, friendly presence that is the description of freedom by him, by protesting 
definitely "your whole universe is not enough to prove me wrong. You are the king of gods, king of stones and stars, king of the waves of the sea. But you are not the king of man" (Sartre, 1989: 65). This phrase voices Sartre who believes that 'God is dead'. Thereupon, Zeus asserts that he gives freedom to them to serve for him. Contrast to his expectation, it becomes a weapon of them towards him. In this context, David Roberts (2006) sets forth "it is in our analysis of the structure of the self, and the rise in selfconsciousness and freedom, that we will discover the source our rebellion against God" (x).

As a natural consequence of his free action, Orestes burdened all responsibility while Electra could not take the responsibility for what she had caused. After all the temptations she made to Orestes she tried to escape from the burden of the action by accusing of him. For example, she charged him with killing their mother by saying "it was you, you who killed them" (Sartre1989: 61). She was not mature or brave enough to grasp the value of 'freedom'. She refused the responsibility and, hence, freedom because freedom is also defined as "as the ability and willingness to ascribe responsibility to our actions as moral and political beings" (Lara, 2007: 110). Electra wanted to evade the responsibility of matricide and the curse of Zeus. Once she accepted what she had caused she could not live in Argos anymore because matricide was the ultimate taboo there. Even though she firstly seemed very courageous and knew what she wanted she just evaded from responsibility, also freedom, and hence performed a bad faith. As Allan Stoekl (2003) announces in his essay, "freedom is a heavy burden to carry, but its very heaviness, its antisocial and cruel (even masochistic) aspect, is what gives it significance. Freedom is the refusal to compromise, to back down, to remember, because all these are functions of remorse, of weakness" (84-5). Instead of denying 'freedom' people have to learn to live in accordance with it. As Charles I. Glicksberg (1948) declares that "man has been made free, and that act cannot be undone" (235).

At the end of the play, Orestes divulges what he had done before leaving the city:

You see me, men of Argos, you understand that my crime is wholly mine; I claim it as my own, for all to know; it is my glory, my life's work, and you can neither punish me nor pity me. That is why I fill you with fear. And yet, my people, I love you, and it was for your sake that I killed. For your sake. I had come to claim my kingdom, and you would have none of me because I was not of your kind. Now I am of your kind, my 
subjects; there is a bond of blood between us, and I have earned riny kingship over you. As for your sins and your remorse, your night-fears, and the crime Aegistheus committed all are mine, I take them all upon me. Fear your dead no longer; they are my dead. And, see, your faithful flies have left you and come to me. (Sartre, 1989: 68)

As it is seen, Orestes accepts the responsibility because one is considered responsible "only if he both knows the particular facts surrounding his action, and acts with the proper sorts of beliefs and intentions" (Mele, 2010: 103). In this sense, he is seen to live authentically by taking all the burden of his act. He did what he believed was right by refusing any external standards whether it be religious, social or psychological. And he left the city alone because as Timothy J. Williams (2008) discusses that "the result is alienation from the great majority of people, who will not appreciate this freedom, and the free individual must endure a profound despair both of absolute moral solitude and from the certainty that there is no metaphysical hope" (376).

In conclusion, the play called the Flies can be considered as a journey of the protagonist Orestes from bad faith to finding his self. At the beginning of the play, he does not know what to do. He feels displaced as he does not know people in Argos. Thus, he cannot claim to the throne. That is why, he decides to consult to Zeus; however, when Zeus tells him to leave he realizes that he may not leave the city if he does not want. This recognition is very important in the sense that he knows his being free. $\mathrm{He}$ will command his life not according to the orders of God or king but according to his own will. This makes him more powerful than Zeus and King Aigestheus. Orestes avenges the death of his father even though he knows that he will be exiled. However, he does not feel remorse for what he has done because he is aware of the fact that he decides who he is as a result of his free choices.

\section{REFERENCES}

Amstutz, J. (1961). Origin and types of existentialism. The Journal of Religion, Vol. 41, No. 4. Retrieved 25.05.2020, from https://doi.org/10.1086/485372

Critch, R. (2013). Principled tyranny: Can Korsgaard explain evil action?. International Journal of Philosophical Studies, 21(2). Retrieved 23.05.2020.

Glicksberg, C. I. (1948). The literature of existentialism. Prairie Schooner, Vol. 22, No. 3, 1948.

Heidegger, M. (1985). Schelling's treatise on the essence of human freedom, (1809), (Trans.: Joan Stambaugh), Ohaio University Press: United States of America. 
Jones, G. E. (1980). Sartre, consciousness, and responsibility. Philosophy and Phenomenological Research, 41(1/2). Retrieved 25.04.2020, from https://www.jstor.org/stable/2107407

Kane, R. (2000). Free Will and responsibility: Ancient dispute, new themes. The Journal of Ethics, Vol. 4, No. 4, Free Will and Moral Responsibility: Three Recent Views.

Ken, G. and Janaway, C. (2006). Nietzsche on free will, autonomy and the sovereign individual. Proceedings of the Aristotelian Society, Supplementary Volumes, Vol. 80. 10.1111/j.0066-7373.2006.00135.x

Lara, M. P. (2007). Narrating evil, A postmetaphysical theory of reflective judgement, New York: Columbia University Press.

Mele, A. (2010). Moral responsibility for actions: Epistemic and freedom conditions. Philosophical Explorations: An International Journal for the Philosophy of Mind and Action. https://doi.org/10.1080/13869790903 494556

Roberts, D. (2006). Kierkegaard's analysis of radical evil. MPG Books Ltd, Bodmin, Cornwall 2006.

Santoni, R. E. (2008). Camus on Sartre's "Freedom": Another misunderstanding. The Review of Metaphysics, Vol. 61, No. 4. Retrieved 23.04.2020, from https://www.jstor.org/stable/20131022

Stoekl, A. (2003). What the Nazis saw: "Les mouches" in occupied Paris. SubStance, Vol. 32, No. 3, Issue 102: The Politics of French Literary History. Retrieved 23.04.2020, from https://www.jstor.org/stable/i287923

Sartre, J. P. (1989). No exit and three other plays. Now York: Vintage International.

Sartre, J. P. (1992). Being and nothingness: A phenemenological essay on ontology (trans. by Hazel E. Barnes), New York: Washington Square Press.

Sartre, J. P. (2007). Existentialism is a humanism, Trans. Carol Macomber, New Heaven \& London:YaleUniversity Press.

Stevenson, (L.) (1983). Sartre on bad faith. Philosophy,58(224), 253-258. Retrieved August 20, 2021, from http://www.jstor.org/stable/3750658

Williams, T. J. (2008). Reflection, reason, and free Will. Philosophical Explorations: An International Journal for the Philosophy of Mind and Action, 10(1).

Çatışma beyanı: Makalenin yazarı bu çalışma ile ilgili taraf olabilecek herhangi bir kişi ya da finansal ilişkileri bulunmadığını dolayısıyla herhangi bir çıkar çatışmasının olmadığını beyan eder.

Destek ve teşekkür: Çalışmada herhangi bir kurum ya da kuruluştan destek alınmamıştır. 